\title{
Nutrient Composition of Mature and Litter Leaves and Nutrient Mobilization in Leaves of Tree Species from Secondary Rainforests in the South of Brazil
}

\author{
Kauana Melissa Cunha Dickow ${ }^{*}$, Renato Marques and Carolina Benghi Pinto \\ Departamento de Solos e Engenharia Agrícola; Universidade Federal do Paraná; Rua dos Funcionários, 1540; \\ 80035-050; Curitiba - PR - Brasil
}

\begin{abstract}
The aim of this work was to analyze the concentration of $N, P, K, C a$ and $M g$ in mature and litter leaves and nutrient mobilization in leaves of different tree species from secondary forests of the Atlantic Forest. At the study site, located in Floresta do Palmito (Paranaguá, PR), three different forest typologies namely Initial, Intermediary and Advanced were selected. The predominant sequence of nutrients in litter leaves was: $N>C a>M g>K>P$. This sequence was very similar to that found for mature leaves, the difference being only the change in order between $\mathrm{Mg}$ and $\mathrm{K}$. Nutrients mobilized in leaves were higher in the typology Advanced compared to the typology Initial, mainly N, P and K. The majority of the species studied did not mobilize Ca to other parts of the plant, except Clusia criuva (typology Intermediary) and Ocotea pulchella (typology Advanced).
\end{abstract}

Key words: Atlantic forest, biogeochemical cycling, forest nutrition, Brazil

\section{INTRODUCTION}

The coast of Paraná State contains some of the best preserved continuous forest remnants of the Atlantic Forest in Brazil. Despite its high importance in biodiversity, this forest has been intensively submitted to anthropogenic influence, causing a drastic reduction of its original surface.

Nutrient cycling is one of the most important processes of the ecosystem, mainly in highly leached soils with low fertility. It comprises assimilation and storage of nutrients in biomass, return to soil via organic matter or leachates, accumulation and decomposition on the soil surface and, finally, mineralization, through which nutrients become available to plants (Mason, 1980;
Haag et al., 1985; Delitti, 1995). Nutrients uptaken by the plants are transported to growing organs, being incorporated in plant tissues or taking part in metabolic processes that guarantee the growth and vitality of plants. During senescence, some of these nutrients are mobilized to other parts of the plant. This mobilization of nutrients through the compartments of the plant, also known as biochemistry cycling, represents an optimisation of the nutrients use by the plants. Little has been studied concerning nutrient cycling of tree species from Atlantic Forest. Thus, the aim of the present work was to study the nutrient composition of mature and litter leaves and the nutrient mobilization in leaves of different tree species from secondary forests in the South of Brazil.

\footnotetext{
* Author for correspondence: kauanadickow@yahoo.com.br
} 


\section{MATERIAL AND METHODS}

\section{Characterization of the area}

The study was carried out in different forest typologies of the "Floresta Estadual do Palmito", located in Paranaguá - PR, between $25^{\circ} 35^{\prime} \mathrm{S}$ and $48^{\circ} 32^{\prime} \mathrm{W}$. The regional climate is defined as Cfa, according to Köppen, described as subtropical humid, with an average temperature of the hottest month higher than $22^{\circ} \mathrm{C}$ and of the coldest month between $-3^{\circ} \mathrm{C}$ and $18^{\circ} \mathrm{C}$, and precipitation of the driest month higher than $60 \mathrm{~mm}$ (IAPAR, 2007).

The original vegetation of the area was described as Lowland Dense Ombrophilous Forest (IBGE, 1992). This vegetation was intensively explored in the past by the extraction of wood and palm tree (to collect palm heart) and some areas were totally deforested and used for agricultural activities. Due to productive limitations of soil in these areas, they were often abandoned after a short period of time, allowing the development of a secondary succession. Actually, the area is characterized by a mosaic of different forest typologies.

For this study, three plots were allocated in the area, each one in a different forest typology. Each plot had an area of $1000 \mathrm{~m}^{2}$, subdivided in $10 \mathrm{sub}$ plots of $100 \mathrm{~m}^{2}$. The typologies were named according to the characteristics of the vegetation:

\section{Initial}

Pioneer formation, where Ilex theazans Marth was the predominant tree species. Other tree species important in the area were: Ternstroemia brasiliensis Cambess, Andira anthelminthica Benth and Ocotea pulchella Marth. The area was formed by a total of 15 tree species and was characterized by only one stratus. The average tree height was of about $5 \mathrm{~m}$. Some trees were originated from sprout of roots which remained in the soil from the previous vegetation. There were few epiphytes and luminosity was high. In the past, the vegetation suffered two clear cuts and was burned after the last intervention (approximately 26 years ago).

\section{Intermediary}

This typology was characterized by two distinct strata and a third one being formed. Twenty two tree species occured in the area. Ilex theazans was the predominant tree species, but not as expressive as in the typology Initial. Other tree species were Ternstroemia brasiliensis, Rapanea venosa DC. (Mez), Gomidesia schaueriana Berg. and Clusia criuva Camb. There were no gaps and the forest was shady and humid. The higher trees reached $12.5 \mathrm{~m}$, while the second storey was around $8 \mathrm{~m}$. The understorey contained a lot of bromeliads and also epiphytes. In the past, the vegetation was cut down and used for agriculture. The area was abandoned approximately 39 years ago.

\section{Advanced}

This typology was characterized by three strata and an understorey full of bromeliads, epiphytes and climbing plants. The overstorey was between 11 and $14 \mathrm{~m}$ height. It had more than 50 tree species, but none was dominant. Some important tree species were Tapirira guianensis Aubl, Ocotea aciphylla (Nees and Mart.) Mez, Andira anthelmintica and Euterpe edulis Mart. The original forest suffered selective cuts of arboreal individuals and the area was abandoned approximately 64 years ago (Wisniewski et al., 1997).

The soil in the three typologies was classified as Podzol. However, there were differences in thickness and depth between the horizons of these soils. The mineral soil was mainly composed by sand, was acidic, presenting low availability of phosphorus, potassium and basic cations. It was important to note that the ground water level of the typology Advanced was nearer to the surface, compared to the two other areas (Schwarzbach, 2005). This characteristic could cause distinct development conditions (growth and species composition) of the vegetation.

As the soil of the study plots present distinct historical usage and environment conditions (e.g. ground water level), the experimental areas were not considered part of a successional chronosequence, but only different forest typologies.

\section{Estimation of Nutrient Mobilization}

The mobilization (M) of $\mathrm{N}, \mathrm{P}, \mathrm{K}, \mathrm{Ca}$ and $\mathrm{Mg}$ from mature to growing leaves (internal cycling) was estimated according to Attiwill et al. (1978):

$\mathrm{M}[\%]=[(\mathrm{Clit}-\mathrm{Cmat}) / \mathrm{Cmat} * 100]$

Where,

Clit $=$ concentration of the element in litter leaves (g.kg-1)

Cmat $=$ concentration of the element in mature leaves $\left(\mathrm{g} \cdot \mathrm{kg}^{-1}\right)$ 
To collect the litterfall, litter traps made of PVC tubes and nylon net, with an area of $0.31 \mathrm{~m}^{2}$ were installed at $0.70 \mathrm{~cm}$ above soil surface in the three plots (Initial, Intermediary and Advanced). Ten litter traps were installed in each plot and collections of litter were made every three weeks, during a period of two years, from autumn 1998 to summer 2000.

In laboratory, litterfall was put into paper bags and air-dried. After drying, the leaves of the selected tree species were separated from the total litterfall. The selection of these species was based on two criteria: species with higher Importance Value (IV) and their occurrence in the litter traps during the study period. The list of the selected species in the three typologies is presented in Table 1 .
After separation, the leaves were oven dried (65 \pm $5^{\circ} \mathrm{C}$ ) and weighed. The samples were combined to one composite sample per season for each tree species prior to chemical analysis. Mature leaves were collected from five trees of each selected species in autumn (May 2000). The leaves were put into plastic bags and transported to the laboratory in isolated boxes.

In laboratory, the leaves were separated according to the growing characteristics of each species, based on the study carried out by Boeger (2000). Only the leaves from the median part of the twig were selected to avoid the use of either very young or very old leaves. The single samples were combined to one composite sample per tree species prior to chemical analysis.

Table 1 - Selected tree species from the forest typologies Initial, Intermediary and Advanced and its respective importance values, in Floresta do Palmito, Paranaguá - PR, Brazil.

\begin{tabular}{clc}
\hline Forest Typology & \multicolumn{1}{c}{ Tree Species } & Importance Value (\%) \\
\hline \multirow{4}{*}{ Initial } & Ilex theazans Mart. (caúna) & 159.6 \\
& Ternstroemia brasiliensis Camb. (vermelho) & 29.2 \\
& Ocotea pulchella Mart. (canela-lageana) & 16.5 \\
& Pera glabrata (Schott) Baill. (tabocuva) & 15.5 \\
\hline & Ilex theazans Mart. (caúna) & 72.9 \\
& Ternstroemia brasiliensis Camb. (vermelho) & 31.7 \\
Intermediary & Rapanea venosa (DC.) Mez (capororocão) & 30.0 \\
& Gomidesia schaueriana Berg. (papagoela) & 29.7 \\
& Clusia criuva Camb. (mangue-do-mato) & 14.4 \\
& Ocotea pulchella Mart. (canela-lageana) & 13.2 \\
\hline \multirow{5}{*}{ Advanced } & Tapirira guianensis Aubl. (cupiúva) & 29.1 \\
& Ocotea aciphylla (Nees and Mart.) Mez (canela ponta-de-lança) & 20.5 \\
& Ocotea pulchella Mart. (canela-lageana) & 16.6 \\
& Myrcia racemosa (O.Berg) Kiaersk. (guapiranga) & 12.5 \\
\hline
\end{tabular}

\section{Chemical Analysis}

The Nitrogen was determined by Kjeldahl Method (Bremner and Mulvaney, 1982). To determine P, $\mathrm{K}, \mathrm{Ca}$ and $\mathrm{Mg}$ of mature and litter leaves, the material was combusted at $500^{\circ} \mathrm{C}$ and dissolved in $10 \% \mathrm{HCl}$ (Perkin-Elmer, 1973). Potassium was analyzed by atomic emission; Calcium and magnesium were analyzed by atomic absorption in Spectrophotometer (Perkin-Elmer 2380). Phosphorus was analyzed by colorimetric method.

\section{RESULTS AND DISCUSSION}

\section{Chemical Composition of Mature Leaves}

The predominant sequence of nutrients in mature leaves, independent of tree species, was: $\mathrm{N}>\mathrm{Ca}>$ $\mathrm{K}>\mathrm{Mg}>\mathrm{P}$ (Table 2). Considering the specific nutrient composition, in the typology Initial, Pera glabrata presented the highest $\mathrm{N}, \mathrm{P}$ and $\mathrm{K}$ concentrations. In the typology Intermediary, Ocotea pulchella presented the highest $\mathrm{P}$ concentration, Rapanea venosa presented the highest $\mathrm{N}$ and $\mathrm{K}$ concentrations and Clusia criuva presented the highest $\mathrm{Ca}$ concentration.

In the typology Advanced, Ocotea aciphylla presented the lowest concentration for the majority of elements analysed. Since till this study, the chemical composition of mature leaves from tree species of the Atlantic Forest had rarely been investigated, comparison of the results obtained here was very limited. However, the nutrient concentrations found in the majority of species were comparable to those found by other studies accomplished in Atlantic Forest at the coast of Paraná State (Boeger, 2005; Britez, 1994; Pires, 
2006; Protil, 2006). These differences among the species were probably genetically related but also seemed to be influenced the by changes in the environment.

Considering the different forest typologies, concentrations of $\mathrm{N}$ and $\mathrm{K}$ were higher in the Advanced and lower in the typology Initial. Concentrations of $\mathrm{P}$ were in the same range in all the three stages. For $\mathrm{Ca}$, except in the case of Clusia criuva, the concentrations in mature leaves were lower for the species in the typology Intermediary, a little higher in the typology Initial and much higher in the Advanced one (except for Ocotea aciphylla). $\mathrm{Mg}$ concentrations were on average highest in the typology Initial. These elevated concentrations of $\mathrm{Ca}, \mathrm{Mg}$ and $\mathrm{Na}$ (data not presented here) in the typology Initial were in accordance with observations made by Boeger et al. (2005) in a previous work in the same area, who related it to the decreasing of the sclerophilic character of leaves as the forest became older. The older forests are composed by trees of different ages and also by a higher variety of species, which are more shadow tolerant and consequently present leaves less sclerophilic. These species occur in an environment presenting a higher availability of nutrients, related to a higher litter decomposition, and by consequence tend to present higher concentrations for most nutrients in its tissues.

Table 2 - Average nutrient concentration $\left(\mathrm{g} \mathrm{kg}^{-1}\right)$ in mature leaves of the selected tree species from the typologies Initial, Intermediary and Advanced in Floresta do Palmito, Paranaguá - PR, Brazil.

\begin{tabular}{llccccc}
\hline \multirow{2}{*}{ Forest Typology } & \multicolumn{1}{c}{ Tree Specie } & $\mathbf{N}$ & $\mathbf{P}$ & $\begin{array}{c}\mathbf{K} \\
\mathbf{g ~ k g}^{-\mathbf{1}}\end{array}$ & $\mathbf{C a}$ & $\mathbf{M g}$ \\
& & & & & \\
\hline \multirow{5}{*}{ Initial } & Ilex theazans & 10.52 & 0.44 & 2.88 & 8.06 & 4.08 \\
& Ternstroemia brasiliensis & 9.97 & 0.39 & 2.45 & 9.45 & 3.28 \\
& $\begin{array}{l}\text { Pera glabrata } \\
\text { Average }\end{array}$ & 18.29 & 0.94 & 4.25 & 8.48 & 3.89 \\
& Ilex theazans & $\mathbf{1 2 . 9 3}$ & $\mathbf{0 . 5 9}$ & $\mathbf{3 . 1 9}$ & $\mathbf{8 . 6 6}$ & $\mathbf{3 . 7 5}$ \\
\hline \multirow{5}{*}{ Intermediary } & 12.16 & 0.55 & 3.98 & 6.29 & 3.89 \\
& Ternstroemia brasiliensis & 9.31 & 0.34 & 4.07 & 6.70 & 3.50 \\
& Ocotea pulchella & 14.79 & 0.72 & 3.72 & 3.97 & 1.09 \\
& Clusia criuva & 10.52 & 0.40 & 3.55 & 15.27 & 3.29 \\
& Rapanea venosa & 20.48 & 0.56 & 6.06 & 4.99 & 1.89 \\
& Gomidesia fenzliana & 10.08 & 0.59 & 5.16 & 4.88 & 2.09 \\
& Average & $\mathbf{1 2 . 8 9}$ & $\mathbf{0 . 5 3}$ & $\mathbf{4 . 4 2}$ & $\mathbf{7 . 0 2}$ & $\mathbf{2 . 6 3}$ \\
\hline \multirow{5}{*}{ Advanced } & 15.32 & 0.59 & 4.80 & 11.00 & 0.70 \\
& Ocotea pulchella & 15.66 & 0.50 & 6.11 & 5.29 & 1.60 \\
& Ocotea aciphilla & 16.32 & 0.80 & 6.06 & 12.46 & 3.19 \\
& Tapirira guianensis & 13.80 & 0.50 & 3.61 & 12.99 & 3.50 \\
& Myrcia racemosa & $\mathbf{1 4 . 8 0}$ & $\mathbf{0 . 5 8}$ & $\mathbf{5 . 0 0}$ & $\mathbf{9 . 7 5}$ & $\mathbf{2 . 3 2}$ \\
\hline
\end{tabular}

\section{Chemical Composition of Litter Leaves}

The nutrient concentration in litter leaves of the selected tree species is shown in Table 3. The predominant sequence of nutrients in litter leaves was: $\mathrm{N}>\mathrm{Ca}>\mathrm{Mg}>\mathrm{K}>\mathrm{P}$. This sequence was very similar to that found for mature leaves, the difference being only the change in order between $\mathrm{Mg}$ and $\mathrm{K}$. This sequence was also similar to that observed by other studies accomplished in tropical forests (Pagano, 1985; Moraes, 1993; Britez, 1994; Gabriel, 1996; Portes, 2000; Rocha, 2006; Protil, 2006).

Concentration of $\mathrm{Ca}$ was higher than $\mathrm{N}$ in litter leaves of Ternstroemia brasiliensis, Clusia criuva, Tapirira guianensis and Myrcia racemosa. On average, the typology Initial presented the highest
$\mathrm{P}, \mathrm{Ca}$ and $\mathrm{Mg}$ concentrations in litter leaves. This effect could be explained by the presence of Pera glabrata in this area. This tree species had very high concentrations of all the elements analyzed. Nitrogen and phosphorus concentrations in litter leaves of $P$. glabrata were four times higher than in litter leaves of I. theazans and T. brasiliensis. K, $\mathrm{Ca}$ and $\mathrm{Mg}$ were two times higher. Thus, the average nutrient concentration in the typology Initial was overestimated because of the high values found in this species.

For I. theazans, the concentrations of $\mathrm{N}$ and $\mathrm{K}$ were higher in the typology Intermediary and the concentrations of $\mathrm{Ca}$ and $\mathrm{Mg}$ were higher in the typology Initial. For $T$. brasiliensis, the concentrations of $\mathrm{N}, \mathrm{K}$ and $\mathrm{Mg}$ were higher in the 
typology Intermediary and the concentration of $\mathrm{Ca}$ was higher in the typology Initial. No such general tendency between the tree species could be observed in the typology Intermediary. C. criuva and $T$. brasiliensis had the highest $\mathrm{Ca}$ and $\mathrm{Mg}$ concentrations in litter leaves, respectively. In litter leaves of $O$. pulchella and $M$. racemosa, all the nutrient concentrations were higher in the typology Advanced.

\section{Nutrient Mobilization}

The nutrient mobilization in plant tissues of the selected tree species from Initial, Intermediary and Advanced stages is presented in Table 4. Only negative values indicated the mobilization (or retranslocation) of the element. The predominant sequence of nutrient mobilization was the following: $\mathrm{K}>\mathrm{N}>\mathrm{P}>\mathrm{Mg}>\mathrm{Ca}$. This sequence was also observed by Protil (2006) in the same study area, but in a different time period. Caldeira et al. (1999) found the sequence $\mathrm{P}>\mathrm{K}>\mathrm{Mg}>\mathrm{N}>$ $\mathrm{Ca}$ for Acacia mearnsii, and Baliero et al. (2004), working with Acacia mangium, reported the sequence $\mathrm{P}>\mathrm{K}>\mathrm{N}>\mathrm{Mg}$. Despite the differences in the order of the elements, $\mathrm{N}, \mathrm{P}$ and $\mathrm{K}$ were mobilized most.

It was important to note that $\mathrm{K}$ was in the first position of the nutrient mobilization sequence. $\mathrm{K}$ is a very soluble mineral element and so, it is intensively leached from litterfall. As the calculation used to estimate nutrient mobilization did not consider the leached quantities, the result could be overestimated. If leaching was considered in the calculation, $\mathrm{K}$ would probably be in a lower position in the sequence, after $\mathrm{N}$ and $\mathrm{P}$.

Besides the high susceptibility of $\mathrm{K}$ to leaching, it is highly mobile in plants. According to Raij (1991), K can be transported over long distances and distributed to new organs. Plant organs are supplied preferentially and so, meristemic tissues and young fruits usually contain higher concentrations of $\mathrm{K}$.

The typology Initial presented the highest $\mathrm{N}$ mobilization $(45.6 \%$, not considering the species Pera glabrata), compared to the typologies Intermediary and Advanced (32.3 and $26.9 \%$, respectively) and the lowest $\mathrm{Ca}$ and $\mathrm{Mg}$ mobilization. The typology Intermediary presented the highest $\mathrm{P}$ mobilization. In a "restinga" ecosystem at the coast of Paraná State, Britez (1994) observed that N, P and K concentrations in litter leaves were lower than in mature leaves and concluded that these elements were redistributed before leaf abscission. Ca concentration increased because of its low mobility. $\mathrm{Mg}$ concentrations remained stable despite its mobility in plant phloem. Nutrients mobilized in leaves were higher in the typology Advanced, mainly N, P and K.

Table 3 - Average nutrient concentration $\left(\mathrm{g} \mathrm{kg}^{-1}\right)$ in litter leaves of the selected tree species from the typologies Initial, Intermediary and Advanced in Floresta do Palmito, Paranaguá - PR, Brazil.

\begin{tabular}{|c|c|c|c|c|c|c|}
\hline Forest Typology & Tree Specie & $\mathbf{N}$ & $\mathbf{P}$ & $\underset{\mathrm{g} \mathrm{kg}^{-1}}{\mathbf{K}}$ & $\mathbf{C a}$ & Mg \\
\hline \multirow{4}{*}{ Initial } & Ilex theazans & $5.56 \mathrm{a}^{*}(1.84)^{* *}$ & $0.32 \mathrm{a}(0.14)$ & $0.99 \mathrm{a}(0.12)$ & 11.78 a (1.77) & $5.38 \mathrm{~b}(0.28)$ \\
\hline & Ternstroemia brasiliensis & 5.58 a (1.67) & $0.34 \mathrm{a}(0.10)$ & $1.21 \mathrm{a}(0.44)$ & $10.41 \mathrm{a}(0.89)$ & $3.51 \mathrm{a}(0.11)$ \\
\hline & Pera glabrata & 20.38 b (1.39) & $1.44 \mathrm{~b}(0.26)$ & $2.24 \mathrm{~b}(0.48)$ & $19.80 \mathrm{~b}(2.95)$ & $7.20 \mathrm{c}(1.46)$ \\
\hline & Average & 10.51 & 0.70 & 1.48 & 14.00 & 5.36 \\
\hline \multirow{7}{*}{ Intermediary } & Ilex theazans & 10.15 c (2.70) & $0.35 \mathrm{bc}(0.11)$ & 1.95 c $(0.52)$ & 7.62 b (0.88) & $3.74 \mathrm{~d}(0.40)$ \\
\hline & Ternstroemia brasiliensis & $7.40 \mathrm{a}(0.74)$ & $0.24 \mathrm{ab}(0.10)$ & 1.78 b c $(0.32)$ & 7.97 b (0.39) & 4.12 e $(0.37)$ \\
\hline & Ocotea pulchella & 9.76 bc (1.69) & $0.40 \mathrm{c}(0.11)$ & $1.19 \mathrm{a}(0.22)$ & $5.73 \mathrm{a}(0.70)$ & $1.78 \mathrm{a}(0.07)$ \\
\hline & Clusia criuva & $6.84 \mathrm{a}(1.98)$ & $0.29 \mathrm{abc}(0.14)$ & $1.81 \mathrm{bc}(0.21)$ & $13.44 \mathrm{~d}(0.52)$ & $3.29 \mathrm{c}(0.14)$ \\
\hline & Rapanea venosa & $8.13 \mathrm{ab}(1.31)$ & 0.22 a $(0.09)$ & $1.35 \mathrm{a}(0.16)$ & $9.72 \mathrm{c}(1.15)$ & $2.47 \mathrm{~b}(0.17)$ \\
\hline & Gomidesia fenzliana & $7.30 \mathrm{a}(1.54)$ & $0.28 \mathrm{abc}(0.12)$ & $1.48 \mathrm{ab}(0.33)$ & $6.52 \mathrm{a}(0.76)$ & $2.48 \mathrm{~b}(0.37)$ \\
\hline & Average & 8.26 & $\mathbf{0 . 3 0}$ & 1.59 & 8.50 & 2.98 \\
\hline \multirow{5}{*}{ Advanced } & Ocotea pulchella & 10.19 a (2.56) & $0.43 \mathrm{ab}(0.16)$ & $1.28 \mathrm{a}(0.31)$ & 6.73 a $(0.48)$ & $1.81 \mathrm{a}(0.11)$ \\
\hline & Ocotea aciphylla & $11.59 \mathrm{ab}(1.39)$ & $0.32 \mathrm{a}(0.10)$ & $1.77 \mathrm{~b}(0.35)$ & $7.50 \mathrm{a}(0.68)$ & $2.05 \mathrm{~b}(0.12)$ \\
\hline & Tapirira guianensis & $10.86 \mathrm{ab}(2.16)$ & 0.36 a $(0.14)$ & 1.96 bc $(0.28)$ & $12.53 \mathrm{~b}(1.22)$ & $2.32 \mathrm{c}(0.18)$ \\
\hline & Myrcia racemosa & $12.51 \mathrm{~b}(1.47)$ & 0.49 b (0.07) & $2.15 \mathrm{c}(0.35)$ & 16.89 c (0.99) & $2.97 \mathrm{~d}(0.39)$ \\
\hline & Average & 11.29 & 0.40 & 1.79 & 10.91 & 2.29 \\
\hline
\end{tabular}


Table 4 - Nutrients mobilized in leaves of selected tree species from the typologies Initial, Intermediary and Advanced in the Floresta do Palmito, Paranaguá - PR, Brazil.

\begin{tabular}{|c|c|c|c|c|c|c|}
\hline Forest Typology & Tree Specie & $\mathbf{N}$ & $\mathbf{P}$ & $\begin{array}{l}\mathbf{K} \\
\%\end{array}$ & $\mathbf{C a}$ & Mg \\
\hline \multirow{4}{*}{ Initial } & Ilex theazans & -47.1 & -27.3 & -65.6 & 46.2 & 31.9 \\
\hline & Ternstroemia brasiliensis & -44.0 & -12.8 & -50.6 & 10.2 & 7.0 \\
\hline & Pera glabrata & 11.4 & 53.2 & -47.3 & 133.5 & 85.1 \\
\hline & Average & -16.3 & 4.4 & -54.5 & 63.3 & 41.3 \\
\hline \multirow{7}{*}{ Intermediary } & Ilex theazans & -16.5 & -36.4 & -51.0 & 21.1 & -3.9 \\
\hline & Ternstroemia brasiliensis & -20.5 & -29.4 & -56.3 & 19.0 & 17.7 \\
\hline & Ocotea pulchella & -34.0 & -44.4 & -68.0 & 44.3 & 63.3 \\
\hline & Clusia criuva & -35.0 & -27.5 & -49.0 & -12.0 & 0.0 \\
\hline & Rapanea venosa & -60.3 & -60.7 & -77.7 & 94.8 & 30.7 \\
\hline & Gomidesia fenzliana & -27.6 & -52.5 & -71.3 & 33.6 & 18.7 \\
\hline & Average & -32.3 & -41.8 & -62.2 & 33.5 & 21.1 \\
\hline \multirow{5}{*}{ Advanced } & Ocotea pulchella & -33.5 & -27.1 & -73.3 & -38.8 & 158.6 \\
\hline & Ocotea aciphylla & -26.0 & -36.0 & -71.0 & 41.8 & 28.1 \\
\hline & Tapirira guianensis & -33.5 & -55.0 & -67.7 & 0.6 & -27.3 \\
\hline & Myrcia racemosa & -9.3 & -2.0 & -40.4 & 30.0 & -15.1 \\
\hline & Average & -26.9 & -32.4 & -62.9 & 13.4 & 33.1 \\
\hline
\end{tabular}

Variations between nutrient concentration of mature leaves and litter leaves are not attributed only to the species, but also depend on soil conditions, vegetation growing and species development (Sharma and Pande, 1988). The majority of the species studied did not mobilize $\mathrm{Ca}$ to other parts of the plant, except for $C$. criuva (Intermediary) and $O$. pulchella (Advanced). According to Bell and Ward (1984), cited by Magalhães and Blum (1999), foliar abscission seemed to generate higher $\mathrm{Ca}$ losses to the plant and produced litter leaves richer in $\mathrm{Ca}$. Calcium is part of plasmalemma and is a structural component of the cellular wall; it has a low mobility and is released mainly by foliar decomposition.

In the majority of species, $\mathrm{Mg}$ was also not mobilized in litter leaves. The only exceptions were I. theazans (Initial), and T. guianensis and $M$. racemosa (Advanced). According to Protil (2006), this behaviour of the $\mathrm{Mg}$ could be related to the availability of the element in soil. Nitrogen mobilization of $I$. theazans was $47.1 \%$ in the typology Initial and $16.5 \%$ in the typology Intermediary. Calcium reservation was $46.2 \%$ in the typology Initial and $21.1 \%$ in the typology Intermediary.

$R$. venosa showed a high $\mathrm{N}, \mathrm{P}$ and $\mathrm{K}$ mobilization $(60.3,60.7$ and $77.7 \%$, respectively) and a high reservation of $\mathrm{Ca}(94.8 \%)$. M. racemosa revealed a very low $\mathrm{N}$ and $\mathrm{P}$ mobilization in comparison to the other species. A reservation of nutrients was observed in litter leaves of $P$. glabrata. In the same area, Boeger et al. (2005) found a lower C/N ratio (26.7) in mature leaves of $P$. glabrata as compared to other species. Considering that plant tissue with a low $\mathrm{C} / \mathrm{N}$ ratio were more easily decomposed (Mason, 1980), it was probable that the leaves of $P$. glabrata lost $\mathrm{C}$ via decomposition (while the leaves were in the traps), causing an $\mathrm{N}$ concentration effect. As $\mathrm{N}$ concentration in litter leaves was higher than in mature leaves, this resulted in negative values of $\mathrm{N}$ mobilization in $P$. glabrata. The elements that presented positive values (mainly $\mathrm{Ca}$ and $\mathrm{Mg}$ ) were not mobilized before leaf abscission.

\section{RESUMO}

O objetivo do presente trabalho foi analisar a concentração de $\mathrm{N}, \mathrm{P}, \mathrm{K}, \mathrm{Ca}$ e $\mathrm{Mg}$ nas folhas maduras e folhas de serapilheira e mobilização destes elementos nas folhas de diferentes espécies arbóreas de florestas secundárias da Mata Atlântica. A área de estudo localiza-se na Floresta do Palmito (Paranaguá, PR), onde foram selecionadas três tipologias florestais, com diferentes idades e estruturas, denominadas tipologia Inicial, tipologia Intermediária e tipologia Avançada.

A seqüência predominante de nutrientes nas folhas de serapilheira foi: $\mathrm{N}>\mathrm{Ca}>\mathrm{Mg}>\mathrm{K}>\mathrm{P}$. Esta sequiência foi muito similar nas folhas maduras, sendo a única diferença a mudança de ordem entre 
o $\mathrm{Mg}$ e o $\mathrm{K}$. Os nutrientes mobilizados foram maiores na tipologia Avançada em relação à tipologia Inicial, principalmente no caso do $\mathrm{N}, \mathrm{P}$ e K. A maioria das espécies estudadas não mobilizou Ca para outras partes da planta, exceto no caso das espécies Clusia criuva (tipologia Intermediária) e Ocotea pulchella (tipologia Avançada).

\section{REFERENCES}

Attiwill, P. M.; Guthrie, H. B.; Leuning, R. (1978), Nutrient cycling in a Eucalyptus oblique (L'Herit) forest. I. Litter production and nutrient return. Australian Journal of Botany, Melbourne, 26, 79-91.

Baliero, F. de C.; Dias, L. E.; Franco, A. A.; Campello, E. F. C.; Faria, S. M. de. (2004), Acúmulo de nutrientes na parte aérea, na serapilheira acumulada sobre o solo e decomposição de filódios de Acacia mangium Wild. Ciência Florestal, 14, n.1, 59-65.

Boeger, M. R. T.; Wisniewski, C.; Reissmann, C. B. (2005), Nutrientes foliares de espécies arbóreas de três estádios sucessionais de Floresta Ombrófila Densa no sul do Brasil. Acta bot. bras., 19, n.1, 167181.

BELL, D. T. and WARD, S. C. Foliar and twig macronutrients $(\mathrm{N}, \mathrm{P}, \mathrm{K}, \mathrm{Ca}$ and $\mathrm{Mg}$ ) in selected species of Eucalyptus used in rehabilitation: sources of variation. Plant and Soil. N. 1, p: 363-376, 1984.

Boeger, M. R. T. Wisniewski, C. (2003), Comparação da morfologia foliar de espécies arbóreas de três estádios sucessionais distintos de Floresta Ombrófila Densa (Floresta Atlântica) no sul do Brasil. Revista Brasil. Bot., 26, n.1, 61-72.

Boeger, M. R. T. (2000), Morfologia foliar e aspectos nutricionais de espécies arbóreas em três estádios sucessionais, de Floresta Ombrófila Densa das Terras Baixas, Paranaguá, PR. PhD Thesis, Universidade Federal do Paraná, Curitiba, Brazil.

Bremner, J.M.; Mulvaney, C.S. (1982), Nitrogen-total. In: Methods of soil analysis. Part 2. Madison, SSSA/ASA, p. 595-624.

Britez, R.M. (1994), Ciclagem de nutrientes minerais em duas florestas da planície litorânea da Ilha do Mel, Paranaguá, PR. Master Thesis, Universidade Federal do Paraná, Curitiba, Brazil.

Caldeira, M.V.W.; Schumacher. M. V.; Pereira, J.C.; Della-Flora. J. B.; Santos, E. M. (1999), Concentração e redistribuição de nutrientes nas folhas e no folhedo em um povoamento de Acacia mearnsii De Wild, no Rio Grande do Sul, Ciência Florestal, 9, n.1, 19-24.
Delliti, W.B.C. (1995), Estudos de ciclagem de nutrientes: instrumentos para a análise funcional de ecossistemas terrestres. Oecologia Brasiliensis, 1, 469-486.

Gabriel, J. L. C. (1996), Florística, Fitossociologia de espécies lenhosas e aspectos de ciclagem de nutrientes em Floresta Mesófila Semidecídua nos municípios de Anhembi e Bofete/SP. PhD Thesis, Universidade Estadual Paulista, Rio Claro, Brazil.

Haag, H. (1985), Ciclagem de nutrientes em florestas tropicais. Fundação Cargill, Campinas.

IAPAR - Instituto Agronômico do Paraná. Disponvível em <http:// www.iapar.br/Sma/Cartas_Climaticas/ Classificacao_Climatica.htm> acesso em 18 jul. 2007.

Magalhães, L. M. S.; Blum, W. E. H. (1999), Concentração e Distribuição de nutrientes nas folhas de espécies florestais, na Amazônia Ocidental. Floresta e Ambiente, 6, n.1, 127-137.

Mason, C. F. (1980), Decomposição. EPU: Ed. da Universidade de São Paulo.

Moraes, R. M. (1993), Ciclagem de nutrientes minerais em mata atlântica de encosta e mata sobre restinga, na Ilha do Cardoso, Cananéia, SP: produção de serapilheira e transferência de nutrientes. Master Thesis, Universidade de São Paulo, São Paulo, Brazil.

Pagano, S. N. (1985), Estudo florístico, fitossociológico e de ciclagem de nutrientes em mata mesófila semidecídua, no município de Rio Claro, SP. Master Thesis, Universidade Estadual de São Carlos, São Carlos, Brazil.

Perkin-Elmer Corp. (1973), Analytical methods for atomic absorption spectrophotometry. Norwalk, CT: Perkin-Elmer Corp., and revised edition, 1982.

Pires, L. A.; Britez, R. M.; Martel, G.; Pagano, S. N. (2006), Produção, acúmulo e decomposição da serapilheira em um restinga da Ilha do Mel, Paranaguá, PR, Brasil.Acta bot. bras., 20, n.1, 173184.

Portes, M. C. G. O. (2000), Deposição de serapilheira e decomposição foliar em Floresta Ombrófila Densa Altomontana, Morro do Anhagava, Serra da Baitaca, Quatro Barras/PR. Master Thesis, Universidade Federal do Paraná, Curitiba, Brazil.

Protil, C. Z. (2006), Contribuição de quatro espécies arbóreas ao ciclo biogeoquímico em Floresta Atlântica na planície litorânea do Paraná. PhD Thesis, Universidade Federal do Paraná, Curitiba, Brazil.

Raij, B. V. (1991), Fertilidade do solo e adubação. Ed. Agronômica Ceres. Piracicaba. 343p.

Rocha, A. A. (2006), Deposição de fitomassa e nutrientes, acumulação e decomposição de serapilheira em três tipologias da Floresta Atlântica, Paranaguá, PR. Master Thesis, Universidade Federal do Paraná, Curitiba, Brazil. 
Schwarzbach, J. (2005), Dinâmica química da solução do solo em três fases sucessionais da floresta Ombrófila Densa das Terras Baixas no litoral do Paraná. Master Thesis, Universidade Federal do Paraná, Curitiba, Brazil.

Sharma, S. C; Pande, P.K. (1989), Patterns of litter nutrient concentration in some plantation ecosystems. Forest Ecology and Management, 29, n.3, 151-163.
Wisniewski, C. (coord.) (1997), Caracterização do ecossistema e estudo das relações solo - cobertura vegetal em planície pleistocênica do litoral paranaense. Projeto Integrado - CNPq, Curitiba, 55p.

Received: July 23, 2007; Revised: April 17, 2008; Accepted: June 29, 2009. 